\section{Regulation with Trinexapac-ethyl and Dew Removal at the Time of Fungicide Application Did Not Influence Dollar Spot Control}

\author{
Yu Huang, John E. Kaminski ${ }^{1}$, and Peter J. Landschoot \\ Department of Plant Science, The Pennsylvania State University, 116 \\ Agricultural Sciences and Industries Building, University Park, PA 16802
}

Additional index words. Sclerotinia homoeocarpa, epidemiology, turfgrass diseases, turfgrass cultural practices, plant growth regulators

\begin{abstract}
Dollar spot, caused by Sclerotinia homoeocarpa F.T. Bennett, is an important disease of creeping bentgrass (Agrostis stolonifera L.) on golf courses in the northern United States. Canopy moisture in the form of dew plays an important role in the development of dollar spot and routine displacement has been shown to reduce disease severity. The use of plant growth regulators (PGRs) is a common management practice for maintaining creeping bentgrass fairways, but their influence on dollar spot is unclear. The objective of this field study was to elucidate the influence of dew removal at the time of fungicide application on dollar spot control in creeping bentgrass regulated by trinexapac-ethyl (TE). Main factors in the study included three dew removal strategies (non-treated, dew removed-mowed, and dew removed-not mowed) before the application of four fungicide treatments (non-treated, chlorothalonil, propiconazole, and iprodione). All fungicide treatments were applied once to turfgrass previously treated with TE or not treated. The presence or absence of dew at the time of fungicide application generally had no influence on fungicide performance with respect to dollar spot control. Based on the results of this study, dew removal before the application of fungicides targeting dollar spot is unnecessary. Applications of TE before fungicides reduced dollar spot severity in some cases, but reductions in symptom expression were limited and did not result in markedly improved dollar spot control.
\end{abstract}

Dollar spot, caused by Sclerotinia homoeocarpa F.T. Bennett, is considered the most economically important disease of golf course turf in the northern United States (Vargas, 2005). Leaf wetness in the form of dew (condensate and plant-generated moisture, including wound exudates and guttation fluid) plays an important role in the development of dollar spot, and displacement of dew in early morning can reduce symptoms by interrupting prolonged leaf wetness required for disease development (Delvalle et al., 2011; Ellram et al., 2007; Nikolai et al., 2001; Williams et al., 1996). In addition to the use of dew removal and other cultural practices, fungicides often are applied throughout the growing season to provide adequate dollar spot disease control.

Mowing practices and dew removal strategies associated with fungicide performance

Received for publication 3 Oct. 2014. Accepted for publication 27 Dec. 2014.

Financial support for this research was provided in part by the Pennsylvania Turfgrass Council.

We acknowledge Dr. Peter Dernoeden (Professor Emeritus, University of Maryland) for reviewing this manuscript and making suggestions for improvement. We also thank Mr. Timothy Lulis for providing technical assistance.

${ }^{1}$ To whom reprint requests should be addressed; e-mailkaminski@psu.edu. when applied in the morning after dew displacement or at noon to a dry canopy when compared with morning applications to dew-covered turf. The authors suggested improved chlorothalonil performance in the absence of dew may be possible because greater amounts of the fungicide adhere to the dry foliage and/or would be less likely to become diluted.

In a recent study, Pigati et al. (2010) concluded that early morning mowing before fungicide applications improved the performance of fungicides compared with plots mowed in the afternoon. Although some information exists for dollar spot control relative to dew removal strategies alone, or after fungicide applications, the impact of dew at the time of fungicide application is still not well understood.

The application of PGRs has become a conventional golf course turf management practice for the regulation of turfgrass growth; suppression of certain weeds; reduction in mowing frequency and clipping yield; and enhancement of turfgrass color, quality, and density (Watschke et al., 1992). TE, paclobutrazol, and flurprimidol are the most commonly used PGRs on golf courses in the United States. Two of these PGRs, flurprimidol and paclobutrazol, have been shown to inhibit growth of $S$. homoeocarpa to a greater extent than TE (Burpee et al., 1996). Field studies have shown that when used in combination with fungicides, flurprimidol and paclobrutrazol enhance dollar spot control (Fidanza et al., 2006; Putman and Kaminski, 2011; Stewart et al., 2007).

Results from research on the influence of TE on dollar spot severity are inconsistent. Field research findings have described neutral, beneficial, or negative effects of TE on fungicide performance for the control of dollar spot. Burpee et al. (1996) found that when TE was applied alone, it had no significant effect on dollar spot, but when applied in combination with chlorothalonil, iprodione, and propiconazole, it enhanced fungicide efficacy in 1 year of the 2-year study. Putman and Kaminski (2011) reported TE had no influence on dollar spot when applied in combination with fungicides. In the absence of fungicides, however, TE has been shown to significantly suppress dollar spot (Golembiewski and Danneberger, 1998; Putman and Kaminski, 2011). In another study conducted by Stewart et al. (2007), TE rarely influenced dollar spot severity or fungicide performance when applied before the onset of dollar spot symptoms. When applied after the onset of symptoms, turf recovery from dollar spot damage after applications of chlorothalonil and propiconazole was significantly delayed within TE-treated plots on some occasions. Stewart et al. (2007) suggested that diminished turf growth resulting from TE applications may reduce fungicide uptake and limit the suppressive effect of the active ingredient, thereby delaying recovery from the outbreak. Several authors have reported TE improved grass tolerance to abiotic stress and may stimulate non-fungistatic mechanisms that 
contribute to disease suppression (Burpee et al., 1996; Golembiewski and Danneberger, 1998; McCann and Huang, 2007; $\mathrm{Xu}$ and Huang, 2010; Zhang and Schmidt, 2000).

The objectives of this research were to: 1) evaluate the influence of dew removal at the time of fungicide application on dollar spot control; and 2) determine the effect of turfgrass regulation by TE on fungicide performance for dollar spot control.

\section{Materials and Methods}

A 2-year field study was conducted at the Joseph Valentine Turfgrass Research Center located in University Park, PA. The site was a 9-year-old mixed stand of 'Penneagle' creeping bentgrass and annual bluegrass (Poa annua L.) (90\%/10\%) maintained similar to a golf course fairway. Soil was a Hagerstown silt loam (fine, mixed, mesic, Typic Hapludalf) with a $\mathrm{pH}$ of 6.6 , Mehlich-3 phosphorus at $224 \mathrm{~kg} \cdot \mathrm{ha}^{-1}$, exchangeable potassium at $0.16 \mathrm{cmol} \cdot \mathrm{kg}^{-1}$ of soil, and a caton exchange capacity of $11.1 \mathrm{cmol}_{\mathrm{c}} \cdot \mathrm{kg}^{-1}$ of soil. Before initiating treatments, the area was mowed three times/week with a John Deere 7500 Precision Cut triplex fairway mower (John Deere, Moline, IL) set to a bench height of $1.3 \mathrm{~cm}$. Clippings were collected in baskets and removed from the site. The site was irrigated as needed to prevent wilt.

The experimental design was a randomized complete split-plot design with four replications, and the experiment was conducted on three separate occasions (Expt. I, late Summer 2011; Expt. II, Spring 2012; and Expt. III, late Summer 2012) in areas adjacent to one another. Whole plots measured $1.8 \mathrm{~m} \times 7.3 \mathrm{~m}$ and subplots measured $0.9 \mathrm{~m} \times$ $1.8 \mathrm{~m}$. Main factors included three dew removal strategies (non-treated, dew removedmowed, and dew removed-not mowed) before the application of three fungicides alone or in combination with the plant growth regulator TE, which served as subfactors.

Dollar spot was allowed to develop to trace levels [i.e., seven dollar spot infection centers/plot or less (DSIC)] in the study areas to ensure the epidemic had begun, as has been done in previous studies (McDonald et al., 2006; Pigati et al., 2010). Fungicide treatments included Daconil Ultrex 82.5 WDG ${ }^{\circledR}$ (chlorothalonil: 2,4,5,6-tetrachloroisophthalonitrile; Syngenta Crop Protection, Greensboro, NC) applied at $8.17 \mathrm{~kg}$ a.i./ha, Banner $\mathrm{Maxx}^{\circledR}$ \{propiconazole: [1-[[2-(2,4-dichlorophenyl)-4propyl-1,3-dioxolan-2-yl]methyl]-1,2,4triazole; Syngenta Crop Protection $\}$ applied at $0.67 \mathrm{~kg}$ a.i./ha, Chipco $26 \mathrm{GT}^{\circledR}{ }^{\circledR}$ [iprodione: 3-(3,5-dichlorophenyl)-N-isopropyl-2,4dioxoimidazolidine-1-carboxamide; Bayer Environmental Science, Montvale, NJ] applied at $2.21 \mathrm{~kg}$ a.i./ha, and a non-treated control. Plant growth regulator treatments included Primo Maxx $^{\circledR}$ \{trinexapac-ethyl: [4(cyclopropyl-a-hydroxymethylene)-3,5-dioxocyclohexanecarboxylic acid ethylester]; Syngenta Crop Protection $\}$ applied at $0.09 \mathrm{~kg}$ a.i./ha and a non-treated control. Creeping bentgrass in plots placed under growth regulation were treated with two applications of TE on a 14-d interval before fungicide application. Thereafter, applications of TE were continued on a 14-d interval until the end of each experiment for a total of five applications to maintain turfgrass growth regulation. Fungicides and dew removal treatments were applied once for each experiment.

For each treatment application event in Expts. I, II, and III, dew removal treatments were initiated between 0700 and $0730 \mathrm{HR}$ and all fungicides were sprayed within 30 min of dew removal. Dew removal treatments consisted of mowing the area with the John Deere 7500 Precision Cut mower (dew removed-mowed), running the mower over the area with the reels disengaged (i.e., dew removed-not mowed), or no dew removal.

Fungicides and TE were applied using procedures shown to provide optimum dollar spot control on fairway height turf with a $\mathrm{CO}_{2}$-pressurized (276 $\mathrm{kPa}$ ) sprayer equipped with an air-induction flat fan nozzle (AI9504E; TeeJet, Wheaton, IL) and calibrated to deliver water at $407 \mathrm{~L} \cdot \mathrm{ha}^{-1}$ (Couch, 1984; Kaminsk and Fidanza, 2009; McDonald et al., 2006). All plots were mowed $1 \mathrm{~d}$ before dew removal and fungicide application and were mowed again $2 \mathrm{~d}$ after treatments. For general maintenance during the experiment, the site was mowed $3 \mathrm{~d} /$ week and clippings collected based on the regular maintenance schedule as described in this section.

Expt. I was conducted in late summer of 2011. The site was fertilized with urea $(46 \mathrm{~N}-0 \mathrm{P}-0 \mathrm{~K})$ at a rate of $11 \mathrm{~kg}$ nitrogen $(\mathrm{N}) /$ ha in Apr. 2011. To control dollar spot, chlorothalonil was applied to the site at $8.17 \mathrm{~kg}$ a.i./ha on 21 July $2011, \approx 4$ weeks before the initiation of fungicide treatments. Trinexapac-ethyl treatments were initiated on 21 July and repeated on 2-week intervals as previously described. Fungicide and dew removal treatments were applied on $17 \mathrm{Aug}$.

Expt. II was conducted in spring of 2012. On 18 Apr. 2012, the experiment site was fertilized with urea at a rate of $11 \mathrm{~kg} \mathrm{~N} / \mathrm{ha}$. Dollar spot became active early in Spring 2012 and therefore chlorothalonil was applied on two occasions at $8.2 \mathrm{~kg}$ a.i./ha and $4.5 \mathrm{~kg}$ a.i./ha on 17 and 24 May, respectively. Trinexapac-ethyl treatments were initiated on 3 May and repeated every 2 weeks as noted previously. Fungicide and dew removal treatments were applied on 31 May.

Expt. III was initiated in late summer of 2012. No additional $\mathrm{N}$ was applied to the experiment area before treatment initiation. To suppress dollar spot within the experiment site, chlorothalonil was applied at $12.6 \mathrm{~kg}$ a.i./ha and $4.5 \mathrm{~kg}$ a.i./ha on 8 and 15 Aug., respectively. Trinexapac-ethyl treatments were initiated on 23 July and repeated on a 2-week interval as previously described. Fungicide and dew removal treatments were initiated on 20 Aug.

Dew present at the time fungicides were applied was quantified by physically blotting the turf canopy with pre-weighed tissue papers (Kleenex; Kimberly-Clark Global Sales, LLC, Neenah, WI). Dew was removed from the leaf surface within a $0.09-\mathrm{m}^{2}$ wooden square frame as previously described (Delvalle et al., 2011; Williams et al., 1998). Dew was quantified from six random locations adjacent to each experimental area, and the tissue papers were weighed immediately to determine the amount of moisture absorbed from the turfgrass canopy.

After fungicides were applied, dollar spot severity was assessed by visually counting the number of DSICs within each plot every 2 to $6 \mathrm{~d}$. Each experiment was concluded when individual infection centers could no longer be distinguished in the most severely affected plots. Total disease severity was assessed for each experiment by determining the area under disease progress curve (AUDPC) The AUDPC values were calculated using the formula: $\sum\{[(y i+y i+1) / 2](t i+1-t i)\}$, where $i=1,2,3, \ldots, n-1$ and $y i$ is the amount of disease (DSICs) at the time $t i$ (in days) of the $i$ th rating (Madden et al., 2007).

Dates used to calculate AUDPC values were 16 Aug. to 22 Sept. in 2011 (Expt. I; $\mathrm{n}=$ 13), 30 May to 10 July in 2012 (Expt. II; $n=$ 15), and 21 Aug. to 24 Sept. (Expt. III; $n=12$ ) in 2012. All analyses of variance were performed using PROC MIXED in SAS Version 9.3 (SAS Institute, Cary, NC). Preplanned contrasts investigating the main effects of dew, fungicide, and PGR as well as their interactions were examined. Means were separated at $P \leq 0.05$ using Tukey's protected least significant difference test.

\section{Results}

Dollar spot was allowed to naturally progress and disease severity was considered moderate to severe (20 DSICs/plot or greater) in all three studies. Based on a plot of the residuals, all DSIC data and AUDPC values required a square root transformation before analyses. A significant experiment effect was observed for AUDPC data $(P=$ 0.0286) and therefore seasonal dollar spot severity was assessed for each experiment independently.

Expt. I. Trace levels of dollar spot (three DSICs or less) were present when fungicide treatments were initiated on 17 Aug. 2011. A significant fungicide effect was first observed $6 \mathrm{~d}$ after treatment (DAT) application (i.e., 23 Aug.) and remained significant $(P<0.0001)$ on 8 of 10 remaining rating dates (Fig. 1). On all 13 rating dates, no differences in DSICs were observed among fungicides, but all fungicidetreated plots had fewer DSICs when compared with the non-treated control.

As the epidemic progressed, and the impact of the fungicides began to deteriorate, the main effect of TE treatment became significant. At 20 DAT application (i.e., 6 Sept.), plots treated with TE had fewer DSICs compared with plots that did not receive TE applications (Fig. 1). Reductions in DSICs from plots treated with TE were observed on five of 13 rating dates and ranged from four to 17 DSIC's (i.e., $13 \%$ to $39 \%$ ) fewer when compared with plots receiving no TE.

At 23 and 26 DAT (i.e., 9 and 12 Sept.), a significant $\mathrm{TE} \times$ fungicide interaction was 
observed (Fig. 1). On these two rating dates, no difference in DSICs was observed between TE treatments within fungicide-treated plots. However, TE significantly reduced disease by

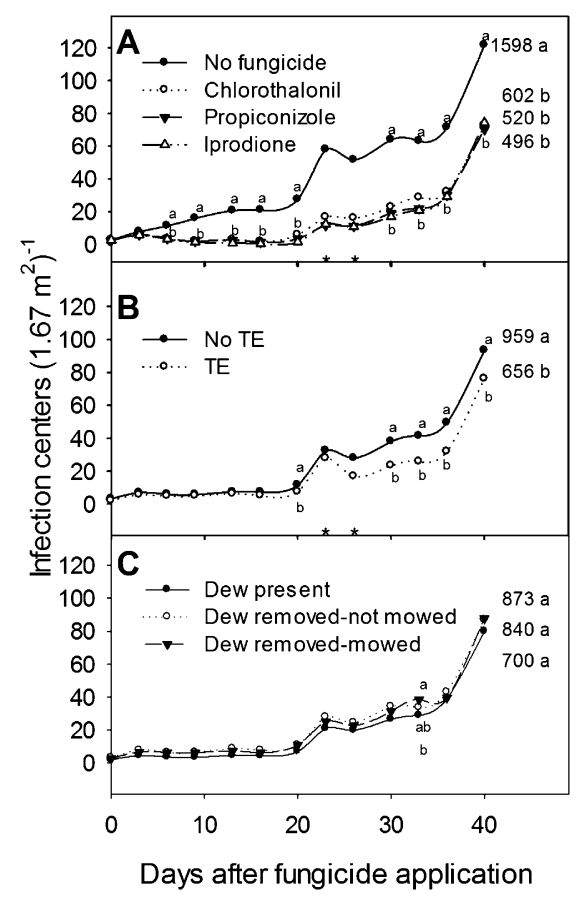

Fig. 1. Dollar spot severity as influenced by the main effect of fungicide across all dew + trinexapac-ethyl (TE) treatments (A), TE across all fungicide + dew treatments (B), and dew removal treatment across all fungicide $+\mathrm{TE}$ treatments $(\mathbf{C})$ on creeping bentgrass maintained as a fairway during late Summer 2011 (Expt. I). Seasonal dollar spot severity (e.g., area under the disease progress curve) for each treatment is shown next to the last rating date. Individual rating dates with significant fungicide $\times \mathrm{TE}$ interactions are labeled with *. For each main effect, means with the same letters are not significantly different at $P \leq 0.05$ according to Tukey's protected least significant difference test.
29 to 38 DSICs (i.e., $44 \%$ to $49 \%$ ) within plots receiving no fungicide (Table 1 ).

A total of $2310 \mathrm{~L}$ dew/ha was present when fungicides were applied on 17 Aug. The main effect of dew treatment was only significant on a single rating date in Expt. I (Fig. 1). On that date (19 Sept., i.e., $33 \mathrm{~d}$ after application), plots that were mowed before the application of fungicides had more DSICs when compared with plots in which dew was not removed, but the difference was less than 10 DSICs.

Expt. II. An average of five to seven DSICs were present when fungicide and dew treatments were initiated on 31 May 2012. Dollar spot was moderate to severe (20 DSICs/plot or greater) during Expt. II and two major peaks in severity were observed during the epidemic (Fig. 2).

Similar to Expt. I, the main effect of fungicide was significant 11 DAT application (i.e., 11 June) and remained significant on all dates throughout the experiment (Fig. 2). Although the greatest number of DSICs was observed in turf within non-treated plots, fewer DSICs were observed in iprodione- vs. chlorothalonil-treated plots on three dates.

The main effect of TE was significant on four of 15 rating dates, including the last three ratings after fungicide performance had waned (Fig. 2). On dates in which the main effect of TE was significant, DSICs within plots treated with TE was reduced an average of one to 19 DSICs (i.e., $20 \%$ to $37 \%$ ).

A significant TE $\times$ fungicide interaction was observed on nine of 15 rating dates (Fig. 2). Similar to Expt. I, differences were observed among TE treatments within plots receiving no fungicide, and no differences among TE treatments were observed among fungicide-treated plots (Table 1).

For Expt. II, a total of $978 \mathrm{~L}$ of dew/ha was present at the time of fungicide application. The main effect of dew was significant at 18 and 24 DAT (i.e., 18 and 24 June). On those dates, plots that were mowed before the application of fungicides had lower DSIC counts when compared with plots in which dew was not removed (Fig. 2). Like in Expt. I, the differences averaged less than 10 DSICs/ plot.

Expt. III. Trace levels of dollar spot (one DSIC) were present when fungicide treatments were initiated on 21 Aug. 2012. Dollar spot developed rapidly for up to 4 weeks after fungicides were applied, but disease levels naturally subsided later in September (Fig. 3). No significant interactions were observed (Fig. 3).

The main effect of fungicide was observed 8 DAT application (i.e., 29 Aug.) and remained significant on all rating dates throughout the experiment (Fig. 3). All fungicides reduced DSICs when compared with the non-treated control, but few differences were observed among fungicides. Similar to Expt. II, plots treated with iprodione generally had the fewest DSICs.

The main effect of TE became significant by 15 DAT application (i.e., 5 Sept.) (Fig. 3). Fewer DSICs were observed within plots treated with TE on eight of 12 rating dates. When compared with the plots not treated with TE, TE-treated turf had fewer DSICs (i.e., eight to $10 \mathrm{DSICs}$ or $12 \%$ to $30 \%$ ).

Dew present at the time fungicides were applied was $1385 \mathrm{~L} \cdot \mathrm{ha}^{-1}$. The main effect of dew, however, was only significant at 17 DAT (i.e., 7 Sept.). On that date, plots in which dew was removed but were not mowed before the application of fungicides had fewer DSICs when compared with plots in which dew was not removed.

Total disease severity for each experiment was assessed by determining AUDPC. Differences among studies existed and therefore AUDPC values for each experiment are reported individually. No significant interactions were present for AUDPC values in any experiment. In all studies, all fungicides provided lower AUDPC values when compared with non-treated control plots. In Studies II

Table 1. Fungicide $\times$ plant growth regulator interactions on dollar spot severity on creeping bentgrass maintained as a golf course fairway. ${ }^{\mathrm{z}}$

\begin{tabular}{|c|c|c|c|c|c|c|c|c|c|c|c|}
\hline \multirow[b]{4}{*}{ Treatment $^{\mathrm{x}}$} & \multicolumn{11}{|c|}{ Dollar spot severity ${ }^{y}$} \\
\hline & \multicolumn{11}{|c|}{ Infection centers $1.67 \mathrm{~m}^{-2}$} \\
\hline & \multicolumn{2}{|c|}{ Expt. I } & \multicolumn{9}{|c|}{ Expt. II } \\
\hline & 9 Sept. & 12 Sept. & 6 June & 8 June & 13 June & 15 June & 18 June & 21 June & 24 June & 26 June & 29 June \\
\hline \multicolumn{12}{|c|}{ Chlorothalonil } \\
\hline No TE & $22 \mathrm{c}^{\mathrm{w}}$ & $22 \mathrm{bc}$ & $4 \mathrm{ab}$ & $4 \mathrm{bc}$ & 2 cde & $5 \mathrm{c}$ & $12 \mathrm{~b}$ & $23 \mathrm{bc}$ & $34 \mathrm{bc}$ & $28 \mathrm{~b}$ & $18 \mathrm{bc}$ \\
\hline $\mathrm{TE}$ & $11 \mathrm{~cd}$ & $10 \mathrm{~cd}$ & $3 \mathrm{~b}$ & $4 \mathrm{bc}$ & 2 cde & $4 \mathrm{c}$ & $10 \mathrm{bc}$ & $16 \mathrm{bcd}$ & $27 \mathrm{bcd}$ & $17 \mathrm{bc}$ & $11 \mathrm{~cd}$ \\
\hline \multicolumn{12}{|c|}{ Propiconazole } \\
\hline No TE & $13 \mathrm{~cd}$ & $13 \mathrm{~cd}$ & $4 \mathrm{ab}$ & $6 \mathrm{bc}$ & $4 \mathrm{bc}$ & $6 \mathrm{c}$ & $7 \mathrm{bc}$ & $12 \mathrm{~cd}$ & $21 \mathrm{~cd}$ & $21 \mathrm{bc}$ & $13 \mathrm{~cd}$ \\
\hline $\mathrm{TE}$ & $11 \mathrm{~d}$ & $10 \mathrm{~d}$ & $4 \mathrm{ab}$ & $6 \mathrm{~b}$ & $3 \mathrm{bcd}$ & $3 \mathrm{c}$ & $4 \mathrm{bc}$ & $8 \mathrm{~d}$ & $11 \mathrm{~d}$ & $8 \mathrm{c}$ & $4 d$ \\
\hline \multicolumn{12}{|l|}{ Iprodione } \\
\hline No TE & $14 \mathrm{~cd}$ & $12 \mathrm{~cd}$ & $2 \mathrm{~b}$ & $1 \mathrm{c}$ & $1 \mathrm{e}$ & $1 \mathrm{c}$ & $2 \mathrm{c}$ & $5 \mathrm{~d}$ & $11 \mathrm{~d}$ & $9 \mathrm{c}$ & $5 \mathrm{~d}$ \\
\hline $\mathrm{TE}$ & $10 \mathrm{~d}$ & $10 \mathrm{~d}$ & $3 a b$ & $3 \mathrm{bc}$ & $1 \mathrm{de}$ & $2 \mathrm{c}$ & $5 \mathrm{bc}$ & $8 \mathrm{~cd}$ & $14 \mathrm{~d}$ & $9 \mathrm{c}$ & $6 \mathrm{~cd}$ \\
\hline \multicolumn{12}{|l|}{ Non-treated } \\
\hline No TE & $77 \mathrm{a}$ & $66 \mathrm{a}$ & $6 \mathrm{a}$ & $15 \mathrm{a}$ & $17 \mathrm{a}$ & $36 \mathrm{a}$ & $45 \mathrm{a}$ & $61 \mathrm{a}$ & $79 a$ & $66 \mathrm{a}$ & $49 \mathrm{a}$ \\
\hline $\mathrm{TE}$ & $39 \mathrm{~b}$ & $37 \mathrm{~b}$ & $3 a b$ & $6 \mathrm{~b}$ & $8 \mathrm{~b}$ & $21 \mathrm{~b}$ & $30 \mathrm{a}$ & $37 \mathrm{~b}$ & $45 \mathrm{~b}$ & $35 \mathrm{~b}$ & $30 \mathrm{~b}$ \\
\hline
\end{tabular}

${ }^{\mathrm{z}}$ Expt. I was conducted during late Summer 2011 and Expt. II was initiated in spring of 2012.

${ }^{\mathrm{y}}$ Dollar spot severity was assessed by counting the number of infection centers per $1.67-\mathrm{m}^{2}$ plot. All data were square root transformed before analyses, but actual means are shown in the table.

xPlant growth regulator treatments included trinexapac-ethyl (TE) applied on 21 July; 4, 17, and 30 Aug.; 14 Sept. in 2011(Expt. I), and on 3, 17, and 31 May; 14 and 28 June in 2012 (Expt. II), and a no-TE treatment. Fungicide treatments were applied on17 Aug. in 2011 and 31 May in 2012.

${ }^{\text {w}}$ Means followed by the same letter are not significantly different at $P \leq 0.05$ according to the Tukey's protected least significant difference test. 


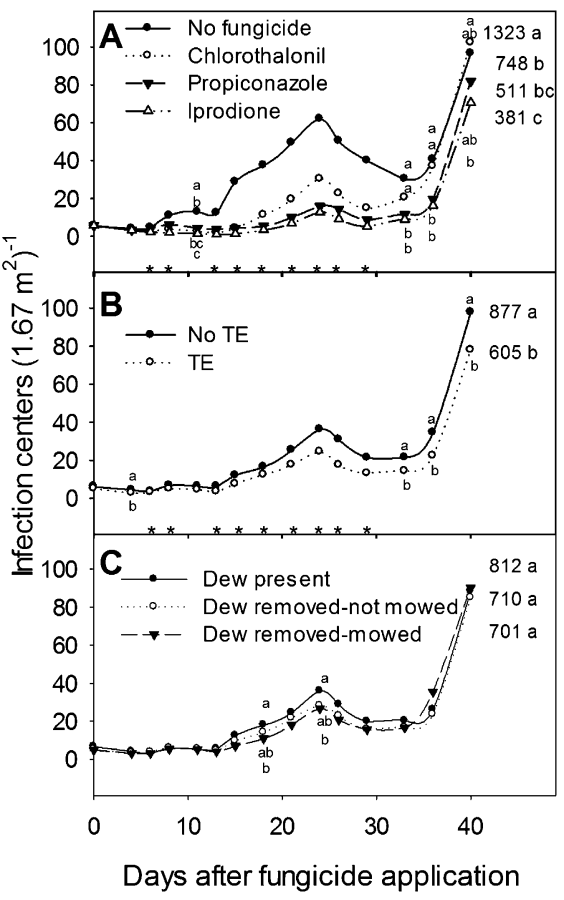

Fig. 2. Dollar spot severity as influenced by the main effect of fungicide across all dew + trinexapac-ethyl (TE) treatments (A), TE treatment across all fungicide + dew treatments $(\mathbf{B})$, and dew removal treatment fungicide $+\mathrm{TE}$ treatments $(\mathbf{C})$ on creeping bentgrass maintained as a fairway during Spring 2012 (Expt. II). Seasonal dollar spot severity (e.g., area under the disease progress curve) for each treatment is shown next to the last rating date. Individual rating dates with significant fungicide $\times$ TE interactions are labeled with *. For each main effect, means with the same letters are not significantly different at $P \leq 0.05$ according to Tukey's protected least significant difference test.

and III, lower AUDPC values were generated with the iprodione treatment when compared with the chlorothalonil treatment (Figs. 2 and 3). Based on AUDPC data, the impact of TE on suppression of DSICs as a main effect was significant in all studies.

To determine the impact of TE on dollar spot severity within plots treated or not treated with a fungicide, planned contrasts were evaluated. No differences in dollar spot severity were observed between PGR treatments (TE vs. no PGR) within plots receiving fungicides. Within plots receiving no fungicide, however, differences were observed on select dates in two of three experiments (Fig. 4). On select dates in Expts. I and II, the use of TE in the absence of fungicides resulted in a significant reduction dollar spot. No differences in dollar spot severity were observed in Expt. III.

\section{Discussion}

The objectives of this 2-year field study were to: 1) evaluate the influence of dew removal at the time of fungicide application on dollar spot control; and 2) determine the effect of turfgrass regulation by TE on fungicide performance for dollar spot control.

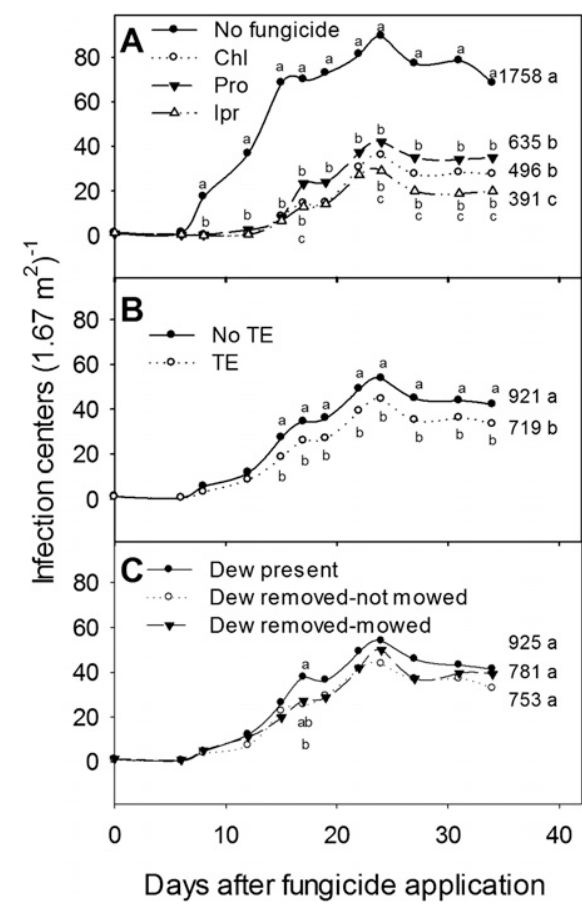

Fig. 3. Dollar spot severity as influenced by the main effect of fungicide across all dew + trinexapac-ethyl (TE) treatments (A), TE treatment across all fungicide + dew treatments $(\mathbf{B})$, and dew removal treatment fungicide $+\mathrm{TE}$ treatments $(\mathbf{C})$ on creeping bentgrass maintained as a fairway during the late Summer 2012 (Expt. III). Fungicides evaluated included chlorothalonil (Chl), propiconazole (Pro), iprodione (Ipr), and a non-treated control. Seasonal dollar spot severity (e.g., area under the disease progress curve) for each treatment is shown next to the last rating date. For each main effect, means with the same letters are not significantly different at $P \leq 0.05$ according to Tukey's protected least significant difference test.

Based on the results of our study using a single fungicide application, the presence or absence of dew at application appears to have little influence on fungicide performance or residual effectiveness, similar to results obtained by McDonald et al. (2006) in the first year of their study. Although the displacement of dew at the time of application has little influence on fungicide performance, the regular displacement of dew has been shown to reduce dollar spot severity (Ellram et al., 2007).

McDonald et al. (2006) observed that the effectiveness of the contact fungicide chlorothalonil in controlling dollar spot was improved on five of 16 rating dates in plots where dew had been displaced vs. dew present in only 1 year of a 2-year study. They also reported no differences in dollar spot control in dew present vs. dew displaced plots treated with propiconazole alone or tank-mixed with chlorothalonil in both study years. McDonald et al. (2006) indicated that in cases in which dew removal was beneficial when using chlorothalonil alone, large quantities of dew remaining on the turfgrass canopy may have diluted or

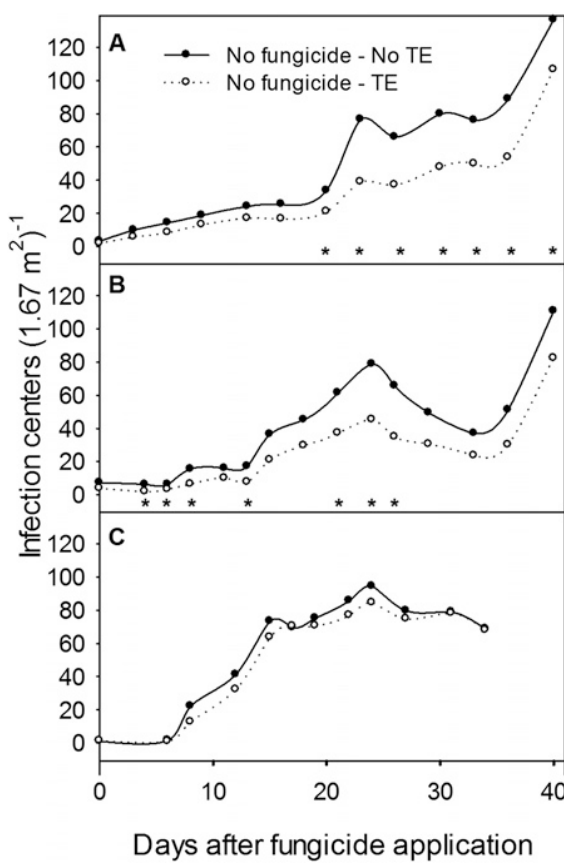

Fig. 4. Dollar spot severity as influenced by the main effect of trinexapac-ethyl (TE) within plots receiving no fungicides on creeping bentgrass maintained as a fairway during late summer of 2012. Data represent dollar spot severity for Expt. I (A), Expt. II (B), and Expt. III (C). For each rating date, means indicated with an * are significantly different at $P \leq 0.05$ according to Tukey's protected least significant difference test.

reduced the amount of chlorothalonil that could adhere to foliage.

Significantly fewer DSICs were observed in plots receiving $\mathrm{TE}$ alone when compared with non-treated control plots (Table 1). Although significant reductions in DSICs were also observed in fungicide-treated plots, this typically occurred after fungicide efficacy had waned and disease severity was pronounced (Figs. 1-3). These results are similar to findings of previous studies in which the impact of TE was more prominent on non-fungicide-treated turfgrass (Golembiewski and Danneberger, 1998; Putman and Kaminski, 2011). In most cases, TE has been shown to have little or no impact on fungicide performance (Fidanza et al., 2006; Putman and Kaminski, 2011; Stewart et al., 2007).

Practical considerations such as drying time after application or traffic on fungicidetreated turf should be taken into account when deciding if dew removal is necessary. When taking other activities on a golf course into account (e.g., foot traffic of golfers and maintenance personnel), the removal of dew before the application of a fungicide may reduce the risk of fungicide displacement before drying and exposure to the golfers.

Although few differences among fungicides occurred in our study, plots treated with iprodione sometimes provided equal or greater dollar spot suppression when compared with chlorothalonil or propiconazole. As a contact fungicide, the residual control of chlorothalonil would be expected to be 
relatively short (less than $14 \mathrm{~d}$ ). Slight differences in dollar spot control between propiconazole and iprodione were expected because this study site has a known history of reduced sensitivity to propiconazole. Latin (2006) suggested that it is likely the chemotherapeutic properties of penetrant fungicides may also account for discrepancies among fungicide field performance trials.

In contrast to our results, Burpee et al. (1996) reported a significant efficacy enhancement of chlorothalonil, iprodione, and propiconazole when applied in combination with TE; but when applied alone, TE did not reduce dollar spot. Burpee et al. (1996) suggested that TE may enhance fungicide performance by minimizing removal of fungicide-treated foliage. Whereas Putman and Kaminski (2011) observed that applications of TE resulted in a reduction in clipping yield, they found that TE did not influence residual fungicide efficacy compared with fungicide-treated plots not treated with TE.

Results of our study indicate that dew removal before a morning fungicide application is generally not advantageous for reducing dollar spot severity or extending fungicide efficacy. Although the application of TE before fungicides reduced dollar spot in our study, the suppression was limited and did not result in commercially acceptable dollar spot control for high-quality golf course fairway turf. In cases where fungicide use is restricted or cost-prohibitive, applications of TE may provide additional suppression.

\section{Literature Cited}

Burpee, L.L., D.E. Green, and S.L. Stephens. 1996. Interactive effects of plant growth regulators and fungicides on epidemics of dollar spot in creeping bentgrass. Plant Dis. 80:1245-1250.

Couch, H.B. 1984. Dilution rates, nozzle size, nozzle pressure, and disease control. Golf Course Mgt. 52:73-80.

Delvalle, T.C., P.J. Landschoot, and J.E. Kaminski. 2011. Effects of dew removal and mowing frequency on fungicide performance for dollar spot control. Plant Dis. 95:1427-1432.

Ellram, A., B. Horgan, and B. Hulke. 2007. Mowing strategies and dew removal to minimize dollar spot on creeping bentgrass. Crop Sci. 47:2129-2137.

Fidanza, M.A., H.C. Wetzel, III, M.L. Agnew, and J.E. Kaminski. 2006. Evaluation of fungicide and plant growth regulator tank-mix programmes on dollar spot severity of creeping bentgrass. Crop Prot. 25:1032-1038.

Golembiewski, R.C. and T.K. Danneberger. 1998 Dollar spot severity as influenced by trinexapacethyl, creeping bentgrass cultivar, and nitrogen fertility. Agron. J. 90:466-470.

Kaminski, J.E. and M.A. Fidanza. 2009. Dollar spot severity as influenced by fungicide mode of activity and spray nozzle. HortScience 44:17621766.

Latin, R. 2006. Residual efficacy of fungicides for the control of dollar spot on creeping bentgrass. Plant Dis. 90:571-575.

Madden, L.V., G. Hughes, and F. van den Bosch 2007. The study of plant disease epidemics. APS Press, St. Paul, MN

McCann, S.E. and B. Huang. 2007. Effects of trinexapac-ethyl foliar application on creeping bentgrass responses to combined drought and heat stress. Crop Sci. 47:2121-2128.

McDonald, S.J., P.H. Dernoeden, and C.A. Bigelow. 2006. Dollar spot control in creeping bentgrass as influenced by fungicide spray volume and application timing. Online Applied Turfgrass Science. doi: 10.1094/ATS2006-0531-01-RS.

Nikolai, T.A., P.E. Rieke, J.N. Rogers, and J.M Vargas, Jr. 2001. Turfgrass and soil responses to lightweight rolling on putting green root zone mixes. J. Intl. Turfgrass Res. Soc. 9:604609.

Pigati, R.L., P.H. Dernoeden, A.P. Grybauskas, and B. Momen. 2010. Simulated rainfall and mowing impact fungicide performance when targeting dollar spot in creeping bentgrass. Plant Dis. 94:596-603.

Putman, A.I. and J.E. Kaminski. 2011. Mowing frequency and plant growth regulator effects on dollar spot severity and on duration of dollar spot control by fungicides. Plant Dis. 95:14331442.

Stewart, J.M., R. Latin, Z. Reicher, and S.G. Hallett. 2007. Influence of trinexapac-ethyl on the efficacy of chlorothalonil and propiconazole for control of dollar spot on creeping bentgrass. Online. Applied Turfgrass Science. doi: 10.1094/ATS-2008-031901-RS.

Vargas, J.M., Jr. 2005. Management of turfgrass diseases. 3rd Ed. Lewis Publ., Boca Raton, FL.

Watschke, T.L., M.G. Prinster, and J.M. Breuninger. 1992. Plant growth regulators and turfgrass management, p. 557-558. In: Waddington, C.V., R.N. Carrow, and R.C. Shearman (eds.). Turfgrass. ASA-CSSA-SSSA, Madison, WI.

Williams, D.W., A.J. Powell, P. Vincelli, and C.T. Dougherty. 1996. Dollar spot on bentgrass influenced by displacement of leaf surface moisture, nitrogen, and clipping removal. Crop Sci. 36:1304-1309.

Williams, D.W., A.J. Powell, Jr., C.T. Dougherty, and P. Vincelli. 1998. Separation and quantification of the sources of dew on creeping bentgrass. Crop Sci. 38:1613-1617.

$\mathrm{Xu}, \mathrm{Y}$. and B. Huang. 2010. Responses of creeping bentgrass to trinexapac-ethyl and biostimulants under summer stress. HortScience 45:125-131.

Zhang, X. and R.E. Schmidt. 2000. Application of trinexapac-ethyl and propiconazole enhances superoxide dismutase and photochemical activity in creeping bentgrass (Agrostis stoloniferous var. palustris). J. Amer. Soc. Hort. Sci. $125: 47-51$. 